\title{
Sustainable development of generation sources in the National Electric Power System
}

ABSTRACT: This article presents an analysis of the sustainable development of generation sources in the Polish National Electric Power System (NEPS). First, the criteria for this development were formulated. The paper also discusses the current status of generation sources, operating in power plants and combined heat and power (CHP) plants of NEPS. Furthermore, it includes a prediction of power balance in NEPS, determining; predicted electricity gross use, predicted demand for peak capacity during the winter peak, predicted demand for peak capacity during the summer peak and required new capacity of centrally dispatched generation units (CDGUs) in 2025, 2030, 2035 and 2040 that would ensure NEPS operational security. Twenty prospective technologies of electricity generation and combined electricity and heat production were analyzed. These were divided into three groups: system power plants, high- and medium-capacity combined heat and power (CHP) plants, as well as small-capacity power plants and CHP plants (dispersed sources). The unit costs of electricity generation discounted for 2021 were calculated for the analyzed technologies, taking the costs of $\mathrm{CO}_{2}$ emission allowances into account. These costs include: capital costs, fuel costs, maintenance costs, operation costs and environmental costs $\left(\mathrm{CO}_{2}\right.$ emission allowances). This proceeds to a proposal of a program of the sustainable development of generation sources in NEPS, which includes the desired capacity structure of power plants and CHP plants, and the optimal structure of electricity

Corresponding Author: Bolesław Zaporowski; e-mail: boleslaw.zaporowski@put.poznan.pl

1 Institute of Electric Power Engineering of Poznań University of Technology, Poznań, Poland; ORCID iD: 0000-0002-8330-3650; e-mail: boleslaw.zaporowski@put.poznan.pl

2021. The Author(s). This is an open-access article distributed under the terms of the Creative Commons Attribution-ShareAlike International License (CC BY-SA 4.0, http://creativecommons.org/licenses/by-sa/4.0/), which permits use, distribution, and reproduction in any medium, provided that the Article is properly cited. 
production in 2030 and 2040. The results of calculations and analyses are presented in tables and figure.

KeYwords: sustainable development, National Electric Power System (NEPS), power plant, combined heat and power (CHP) plant, electricity generation costs

\section{Introduction}

One of the biggest challenges of the current global economy lies in the necessity to conduct an energy transformation to achieve climate neutrality on Earth, i.e. the ecosystem equilibrium between the emission and absorption of greenhouse gases, most importantly: of carbon dioxide. In 2019, the carbon dioxide emission reached $43 \mathrm{bln}$ tons, while its concentration in the atmosphere revolved around $415 \mathrm{ppm}$ (particles per million). This triggered an increase in the Earth temperature by $1.25^{\circ} \mathrm{C}$, in comparison to the pre-industrial period, and alarming climate changes. In 1900, carbon dioxide emission was at the level of 2 bln tons, while its concentration in the atmosphere revolved around $288 \mathrm{ppm}$. Fuel-burning appliances, burning fossil fuels such as coal, petroleum fuels and natural gas, in facilities such as power plants and CHP plants, constitute the biggest $\mathrm{CO}_{2}$ emitters. The global fossil fuel consumption is unfortunately still high and reached the level of circa 11.06 bln toe (462.8 EJ) in 2020 (BP 2021).

In 2015, at the $21^{\text {st }}$ session of the Conference of the Parties to the United Nations Framework Convention on Climate Change (12/12/2015), 189 countries, following several years of international negotiations, reached the Climate Agreement (Paris Agreement), which was signed by Poland on the April 27, 2016, in the UN headquarters in New York. Subsequently, the Polish Seym passed the ratification act on October 6, 2016. According to the Agreement, countries which ratified it are bound to reach climate neutrality by a self-declared deadline. Most parties, including the European Union, declared reaching climate neutrality by 2050. Consequently, in 2020, the European Council took a decision to reduce $\mathrm{CO}_{2}$ by $55 \%$ in the EU Member States by 2030 , as a mid-step towards reaching full neutrality by 2050 . Poland is bound to observe both the Paris Agreement and the European Council's decision of December 2020. The biggest challenges stemming from these documents relate to the electricity generation sector.

This article attempts to discuss the long-term strategy for developing the generation sector of the Polish electric power system, taking the need to reduce $\mathrm{CO}_{2}$ emission into account. The basis for this discussion lies in Article 5 of the Polish Constitution, which obliges Poland to protect the environment, following the rule of sustainable development. In reference to the electric power system's sustainable development, the gist of this rule lies in ensuring the country's economic development, while at the same time protecting the ecosystem equilibrium. Taking that into account, the sustainable development of the generation sector of the Polish electric power system should meet three criteria: (1) ensure the safe work of the National Electric Power Sys- 
tem (NEPS), (2) ensure electric energy availability at a possibly accessible price (generated at a possibly low cost), which contributes to the country's economic development, and (3) ensure the environment protection and counteract climate changes by minimizing unit $\mathrm{CO}_{2}$ emission ( $\mathrm{kg} \mathrm{CO}_{2} / \mathrm{kWh}$ ) during electricity production (Zaporowski 2016).

Searching for the way to reach the sustainable development of generation sources in NEPS consists in finding the equilibrium among environmental protection goals, electricity generation costs and electricity supply safety.

\section{Status of generation sources in the National Electric Power System}

As of June 30,2021, the installed capacity of generation sources in NEPS was about $51.4 \mathrm{GW}$, with $40.2 \mathrm{GW}$ in power plants and $11.2 \mathrm{GW}$ in combined heat and power (CHP) plants (ARE 2021).The largest generation potential of power plants' installed capacity is offered by condensing steam units, with a total installed capacity of circa $25.6 \mathrm{GW}$. These include 8 modern supercritical steam units with a unit capacity ranging from $460 \mathrm{MW}$ to $1,075 \mathrm{MW}$, fired with hard coal and lignite, 81 subcritical steam units with a unit capacity ranging from $60 \mathrm{MW}$ to $560 \mathrm{MW}$, fired with hard coal and lignite, 3 subcritical steam units, burning coke oven gas, and 4 subcritical steam units, fired with biomass. A significant generation potential, very important for the NEPS secure operation, is represented by 11 units in pumped-storage hydroelectric power plants with a total capacity of 1,413 MW and over 2,500 units in run-of-river power plants with a total capacity of circa $983 \mathrm{MW}$. The capacity of the power plants using renewable energy sources (RES), in addition to the capacity of the already mentioned hydroelectric power plants and biomass-fired power plants, comprises the capacity of onshore wind power plants of 6,696.5 MW and photovoltaic power plants of 5,357.0 MW (ARE 2021).

The second group of generation sources operating in the Polish NEPS is CHP units. Their total installed electricity capacity is circa $11.2 \mathrm{GW}$, which accounts for about $22.3 \%$ of the installed capacity in NEPS. In 2019, CHP-generated power accounted for about $16.4 \%$ of all electric power generation in Poland and for about $21.5 \%$ of electric power sold to end users (Statistics 2020), while the share of heat generated in CHP plants in the total production of system heat was circa 65\% (Statistics 2019). The CHP units exhibit significant technological diversity. The largest production potential is offered by CHP steam units, whose installed capacity amounts to circa $7.9 \mathrm{GW}$, representing about $70.5 \%$ of the electrical capacity of all cogeneration sources operating in NEPS. These include CHP units fired with hard coal, natural gas, coke oven gas, biomass and municipal waste. Modern CHP units are natural gas-fired gas-steam units, built in 1999-2020, with a total installed capacity of circa 2,547 MW. One interesting group of CHP units is natural gas-fired simple-cycle gas turbine units, with a total installed capacity of about 194 MW. 
Gas-fired CHP units with gas engines, with a total installed electric capacity of over $500 \mathrm{MW}$, are an important and developing technology. These CHP units burn natural gas or gas from mine degassing or biogas produced in the process of biological conversion of biomass chemical energy into biogas chemical energy in biogas plants (agricultural, sewage treatment plants and municipal waste landfills). There are also several biomass-fired Organic Rankine Cycle (ORC) CHP units operating in NEPS, with a total installed capacity of about 11 MW (Statystyka 2020). Out of more than 760 different types of CHP units operating in NEPS, only 4 ( 2 steam units and 2 gas-steam units), with a total installed capacity of circa 1,380 MW, function to a limited extent as centrally dispatched generation units (CDGUs) in NEPS.

In recent years, NEPS has witnessed a significant increase in the capacity of distributed generation sources (non-CDGUs), particularly in the form of RES-based generation units and, to a lesser extent, cogeneration sources whose operation (output) depends on weather conditions or heat demand in district heating systems. The growth of non-CDGU capacity in the Polish NEPS will continue in the coming years. Therefore, in order to ensure the security of NEPS operation, it is necessary to simultaneously increase the new capacity of CDGUs, whose capacity in the NEPS will be decreasing due to the decommissioning of coal-fired condensing steam units, while demand for capacity in NEPS will be growing. The CDGUs operating in NEPS are highly diversified in terms of energy efficiency, their technical condition and flexibility in responding to load changes. A significant number of them, with a total capacity of about $10 \mathrm{GW}$, have been operating in NEPS for over 40 years and their operation time has exceeded 200,000 hours. Therefore, a significant number of them are expected to be decommissioned in the coming years (PSE 2016, 2020).

\section{National Electric Power System operational security}

Criteria that need to be met by the sustainable development of generation sources in NEPS were formulated in the Introduction. The primary objective of sustainable development of the electric power system is to ensure the security of electricity supply to consumers at a moderate price while protecting the environment. The overarching criterion of the generation sources' sustainable development is ensuring NEPS secure operation. NEPS secure operation is based on the equilibrium between the demand for electrical capacity and the capacity of generation sources (Directive 2005/89). The capacity and technical condition of CDGUs determines the secure and stable functioning of NEPS. As of December 31, 2020, the CDGUs' installed capacity was circa $28.1 \mathrm{GW}$. These include: condensing steam units fired with hard coal and lignite, with a unit capacity of more than $200 \mathrm{MW}$, connected mainly to the transmission grids of $440 \mathrm{kV}$ and $220 \mathrm{kV}$ and partially to the $110 \mathrm{kV}$ distribution grids, pumped-storage hydroelectric units, two coal-fired steam CHP units and three gas-steam CHP units fired with natural gas. $87.6 \%$ of the total CDGUs' capacity comes from coal-fired steam units, including: 
3 steam units of unit capacity equal to $200 \mathrm{MW}$ that have been operating at least 50 years within NEPS,

- 22 steam units of unit capacity equal to $200 \mathrm{MW}$ that have been operating from 46 up to 50 years in NEPS,

$\checkmark 16$ steam units of unit capacity equal to $200 \mathrm{MW}$ that have been operating from 40 up to 45 years in NEPS.

These coal- and lignite-fired units will most likely be decommissioned in the next ten to twenty years. By that time, only three new gas-steam condensing units will have been added to NEPS, i.e.: two gas-steam units of capacity equal to 1,400 MW in the Dolna Odra power plant and one of $700 \mathrm{MW}$ in the Ostrołęka power plant, as well as one cogeneration gas-steam unit of 499 MW in the Żerań CHP plant, all fired with natural gas. This will result in a significant power deficit in NEPS' CDGUs, threatening its operational security. By the same token, there will be a need to replace the decommissioned coal-fired condensing steam units with new zero-emission CDGUs characterized by continuity and stability of operation - at present, these can only be nuclear units. In fact, the CDGUs' fuel transformation constitutes a very important challenge related to the obligatory technological transformation of NEPS, as this ensures NEPS operational security.

Poland's scarce domestic resources of natural gas, its limited resources globally, the lack of a fully liberal international market for this fuel and its high per-unit energy cost (circa PLN 30/GJ) make it impossible, in the long term, to consider natural gas as a strategic fuel for low-emission CDGUs, which are intended to ensure the security of NEPS operation. Moreover, gas -fired gas-steam condensing units are also a source of $\mathrm{CO}_{2}$ emissions at a level of circa $45 \%$ of emissions from coal-fired power plants. Therefore, from the point of view of NEPS operation security, CDGUs in the form of coal-fired condensing steam units being withdrawn from operation should be replaced by zero-emission nuclear units, and they may only be partially replaced by natural gas-fired gas-steam CHP units. Natural gas in the electric power industry in Poland should be used primarily as a fuel for high efficiency CHP units whose overall effectiveness (conversion of chemical energy of fuel into electricity and heat) exceeds 80\% (Directive 2012/27).

The required capacity of CDGUs to ensure the secure and stable operation of NEPS depends on the following factors: capacity demand during winter and summer peaks, average annual capacity demand, and the available capacity of non-CDGUs. Predicted values of gross electricity consumption, the NEPS load in the winter and summer peaks, the required capacity of CDGUs and the capacity of distributed sources are presented in Table 1, cumulatively for 2025, 2030, 2035 and 2040. The values of gross power consumption were determined on the basis of an analysis of annual increments in this consumption in NEPS for 2000-2019, assuming an annual growth rate of $1.27 \%$ for $2020-2050$. The projected demand for NEPS peak capacity for the winter and summer peaks as well as planned decommissioning of CDGUs was based on a study by the grid operator, Polish PSE SA (PSE 2016, 2020) and on a report of the Energy Regulatory Office (URE 2020). 
TABLE 1 . Predicted capacity balance in NEPS in 2025-2040

TABela 1. Prognoza bilansu mocy w KSE w latach 2025-2040

\begin{tabular}{|l|r|r|r|c|}
\hline Years & 2025 & 2030 & 2035 & 2040 \\
\hline Predicted electricity gross use [TWh] & 190.7 & 203.1 & 216.4 & 230.5 \\
\hline $\begin{array}{l}\text { Predicted demand for peak capacity during the winter peak } \\
\text { [GW] }\end{array}$ & 30.3 & 23.7 & 35.2 & 38.1 \\
\hline $\begin{array}{l}\text { Predicted demand for peak capacity during the summer peak } \\
\text { [GW] }\end{array}$ & 27.5 & 30.5 & 32.7 & 36.1 \\
\hline Planned decommissioning of CDGUs [GW] & 1.3 & 3.1 & 6.2 & 10.3 \\
\hline $\begin{array}{l}\text { Planned construction of new CDGUs (natural gas-fired gas- } \\
\text {-steam units) [GW] }\end{array}$ & 1.9 & 2.6 & 2.6 & 2.6 \\
\hline $\begin{array}{l}\text { Predicted capacity of CDGUs after decommissioning and } \\
\text { construction of planned new CDGUs [GW] }\end{array}$ & 28.7 & 27.6 & 24.5 & 20.4 \\
\hline Predicted capacity of distributed sources (non-CDGU) [GW] & 30.3 & 40.7 & 46.2 & 52.1 \\
\hline Required new capacity of CDGUs [GW] & & 1.0 & 4.0 & 8.0 \\
\hline
\end{tabular}

\section{Generation technologies with future potential for Polish electric power industry}

The current status of NEPS' generation sources determines their further development, and this paper assumes that it should proceed in three groups of sources:

$\downarrow$ system power plants,

$\downarrow$ high- and medium-capacity CHP plants, operating in city and industrial heating systems,

$\checkmark$ small capacity power plants and CHP plants (dispersed sources).

Within these three groups, 20 technologies of generating electric energy were selected for the analysis. First, the analysis included 4 system power plants' (CDGUs) technologies, burning: hard coal and lignite, natural gas and nuclear fuel. It was assumed that the power plants burning hard coal and lignite would involve the technology used in supercritical steam units (ultra-supercritical), which is currently the single commercially mature technology of generating electricity out of coal. Natural gas-fired power plants were assigned the technology used in gas-steam units, with 3-pressure heat recovery steam generator and interstage steam reheating, with 4th generation gas turbines. For nuclear power plants, the technology of nuclear units with the third-plus generation of water pressure reactors PWR was chosen.

In the large, medium and small capacity CHP plant group, 11 cogeneration technologies were selected for analysis, which can be employed in CHP units with a combined heat capacity from several dozen $\mathrm{kW}$ to several hundred MW, as they operate simultaneously in NEPS as electricity 
sources and in heating systems of various capacities as heat sources. The group of 11 cogeneration technologies selected for the analysis includes: 5 technologies fueled with natural gas, 5 technologies fueled with biomass or biogas, and 1 coal-fueled technology.

Due to its technical and ecological properties, natural gas can be considered an acceptable fuel for cogeneration units in the transition period of the next 20 years, until Poland reaches full climate neutrality. The natural gas' chemical energy in cogeneration units can be used with the efficiency of more than $80 \%$. The heat capacity in cogeneration units needs to be adjusted to heat demand in the heating system. For this reason, this paper analyses generation technologies that can be used in cogeneration units fired with natural gas, of cogeneration heat capacity ranging from several dozen $\mathrm{kW}$ to several hundred MW, i.e. (Zaporowski 2019):

$\checkmark$ gas-steam CHP unit with 3-pressure heat recovery steam generator (HRSG) and interstage steam reheating,

$\checkmark$ gas-steam CHP unit with 2-pressure HRSG,

$\checkmark$ gas-steam CHP unit with 1-pressure HRSG,

$\checkmark$ gas CHP unit with a simple cycle gas turbine,

$\downarrow$ gas CHP unit with a gas engine.

When it comes to cogeneration technologies using biomass or biogas, the analysis included

(Zaporowski 2019):

$\downarrow$ medium-capacity steam CHP unit,

$\checkmark$ small-capacity ORC (Organic Rankine Cycle) CHP unit,

$\checkmark$ small-capacity steam CHP unit,

$\checkmark$ gas CHP unit integrated with biological biomass conversion,

$\downarrow$ gas CHP unit integrated with biomass gasification.

As for cogeneration technologies using hard coal as the fuel, the analysis included (Zaporowski 2019):

$\checkmark$ medium-capacity subcritical steam CHP unit.

Also, the following generation sources of small-capacity power plants (dispersed sources), using RES, were analyzed:

$\downarrow$ onshore wind power plant,

$\downarrow$ offshore wind power plant,

$\checkmark$ micro photovoltaic power plant of circa $5 \mathrm{~kW}$ capacity,

$\downarrow$ photovoltaic power plant of circa $1 \mathrm{MW}$ capacity,

$\downarrow$ photovoltaic power plant of circa 100 MW capacity. 


\section{Economic effectiveness of the analyzed generation technologies}

The sustainable development of NEPS generation sources should translate into both zero- or low emission and high economic effectiveness. The unit costs of electricity generation discounted for 2021 were selected as the criterion of the analyzed technologies' economic effectiveness. These costs allow the economic effectiveness of different electricity generation technologies used both in power plants and CHP plants to be compared. The unit costs of electricity generation directly include such properties of particular technologies as energy effectiveness and environmental impact $\left(\mathrm{CO}_{2}\right.$ emission allowances costs).

The unit costs of electricity generation in power plants and CHP plants, discounted for 2021, were calculated assuming as input data the energy effectiveness and unit $\mathrm{CO}_{2}$ emissions of each generation technology (Zaporowski 2019), as well as:

$\checkmark$ construction duration of: 6 years for a nuclear power plant, 4 years for a coal-fired or biomass-fired steam power plant, or CHP plant, 2 years for natural gas-fired power plant or CHP plant, and 1 year for a dispersed source,

४ heat sale price of $46.22 \mathrm{PLN} / \mathrm{GJ}$,

$\checkmark$ discount rate: $7.5 \%$ for a nuclear power plant or a coal-fired steam power plant or CHP plant, $7 \%$ for a natural gas-fired power plant or CHP plant, and $6.5 \%$ for dispersed sources.

The unit costs of electricity generation in a power plants or CHP plants include: capital costs, fuel costs, maintenance costs, operation costs and environmental costs $\left(\mathrm{CO}_{2}\right.$ emission allowances $)$. The $\mathrm{CO}_{2}$ emission allowance costs were assumed at $248 \mathrm{PLN} / \mathrm{MgCO}_{2}\left(55 \mathrm{Euro} / \mathrm{MgCO}_{2}\right)$. The results are shown in Figure 1.

\section{A proposal for the program of sustainable development of the National Electric Power System generation sources}

The proposed program of sustainable development of NEPS generation sources includes the period until 2040, as the same period was covered in the „Energy Policy of Poland until 2040" approved by the Polish Government (PEP2040 2021; KPEiK 2019). The proposal results from calculations and analyses where the following steps were made: (1) the calculated CDPGUs' capacity needed for NEPS' secure operation includes the capacity of electric power units of system coal-fired and nuclear power plants, the capacity of natural gas-fired gas-steam cogeneration units with extraction-condensing turbines whose unit capacity exceeds $200 \mathrm{MW}$, the capacity of coal-fired steam cogeneration units extraction-condensing turbines whose unit capacity exceeds $100 \mathrm{MW}$ and the capacity of pumped-storage hydroelectric power plants; 
(2) small-capacity plants (dispersed sources), due to the required high energy effectiveness (optimal use of primary energy), except for hydro, wind and solar power plants, were analyzed solely as cogeneration units (Directive 2012/27); and: (3) the capacity of power plants and CHP plants using RES, and of nuclear power plants, was calculated as a derivative of Poland's obligations to reduce $\mathrm{CO}_{2}$ emission under the Climate Agreement and the European Council's decision of December 2020. The results of calculations and analyses for the period till 2030 and 2040 are presented in Table 2.

TABLE 2. A prediction of the desired structure of power plants' and CHP plants' capacity and the structure of electricity production in 2030 and 2040

TABELA 2. Prognoza pożądanej struktury mocy elektrowni i elektrociepłowni oraz produkcji energii elektrycznej w latach 2030 i 2040

\begin{tabular}{|l|r|r|r|r|r|r|}
\hline \multirow{2}{*}{$\begin{array}{l}\text { Kind of primary energy } \\
\text { (fuel or RES kind) }\end{array}$} & \multicolumn{5}{|c|}{$\begin{array}{c}\text { A prediction of the desired structure of power plants' and CHP plants' capacity and } \\
\text { the structure of electricity production in 2030 and 2040 }\end{array}$} \\
\cline { 2 - 7 } & \multicolumn{5}{|c|}{2030} & \multicolumn{3}{c|}{2040} \\
\cline { 2 - 7 } & GW & TWh & $\%$ & GW & TWh & $\%$ \\
\hline Hard coal and lignite & 28.1 & 112.9 & 55.6 & 16.5 & 60.4 & 26.2 \\
\hline Nuclear fuel & & & & 5.0 & 39.0 & 16.9 \\
\hline Natural gas & 6.6 & 25.1 & 12.4 & 8.4 & 32.8 & 14.2 \\
\hline Biomass and biogas & 2.6 & 10.8 & 5.3 & 3.6 & 14.5 & 6.3 \\
\hline Water & 2.5 & 2.7 & 1.3 & 2.7 & 2.9 & 1.3 \\
\hline Wind (onshore) & 9.6 & 18.2 & 9.0 & 10.5 & 19.9 & 8.6 \\
\hline Wind (offshore) & 5.9 & 20.1 & 9.9 & 11.8 & 40.1 & 17.4 \\
\hline Sun & 14.0 & 13.3 & 6.5 & 22.0 & 20.9 & 9.1 \\
\hline Total & 69.3 & 203.1 & 100.0 & 80.5 & 230.5 & 100.0 \\
\hline
\end{tabular}

The tentative program for sustainable development of the National Electric Power System generation sources (Table 2) assumes the following shares of zero-emission sources (using RES and nuclear fuel) in electricity production: $32 \%$ in 2030 and $59.6 \%$ in 2040.

In addition, the following anticipated values which Poland should reach in 2050 on its path to achieve climate neutrality were calculated:

$\checkmark$ electricity production (electric power gross use): $261.5 \mathrm{TWh}$,

$\checkmark$ system heat production (system heat gross use): $147.7 \mathrm{TWh}$,

$\checkmark$ installed electric capacity of power plants and CHP plants: $92.0 \mathrm{GW}$,

$\checkmark$ electricity generation fuel structure: hard coal and lignite: $6 \%$, nuclear power: $24,7 \%$, natural gas $12.5 \%$, wind energy: $34.0 \%$, sun energy: $14.5 \%$, biomass and biogas: $7.2 \%$, and water energy: $1.1 \%$. 


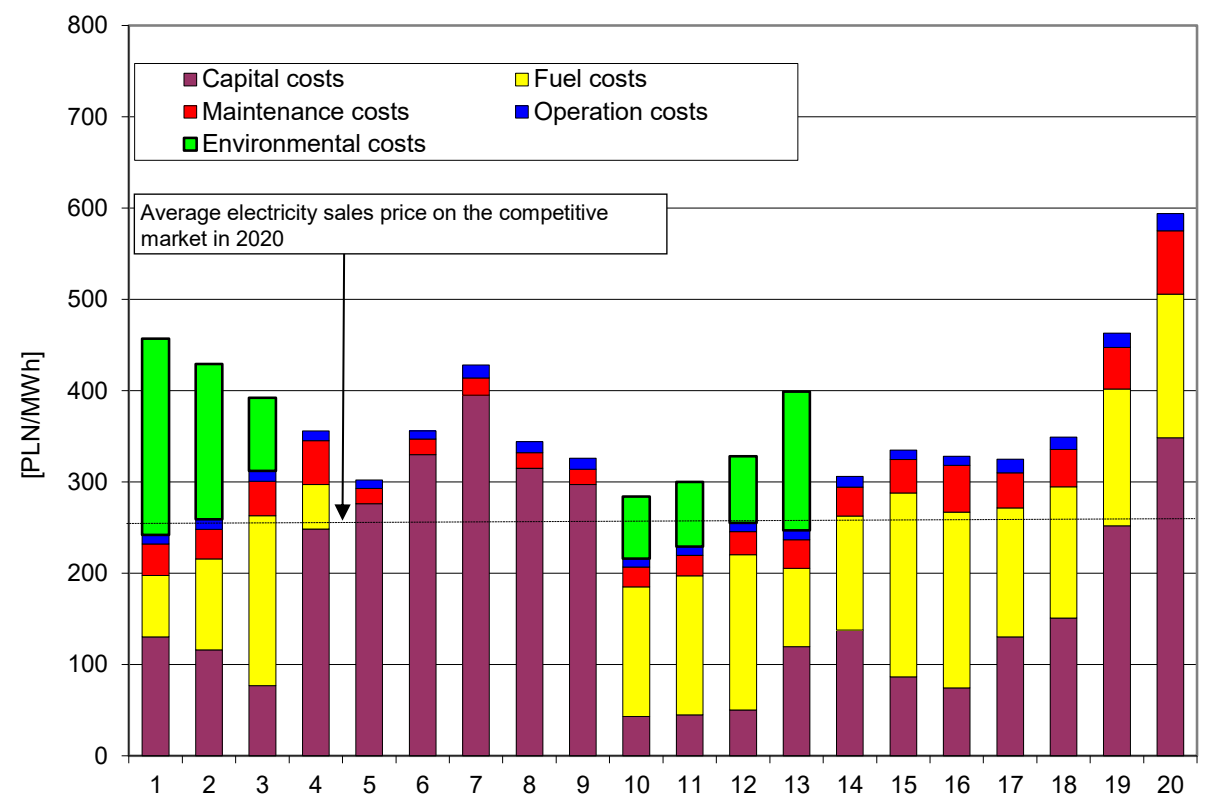

Fig. 1. Unit electricity generation costs, discounted for 2021, in system power plants, large and medium capacity CHP plants, and small capacity power plants and CHP plants [PLN/MWh], for: 1) lignite-fired supercritical steam unit,

2) hard coal-fired supercritical steam unit, 3) natural gas-fired gas-steam unit, 4) nuclear unit with PWR reactor, 5) onshore wind power plat, 6) offshore power plant, 7) $5 \mathrm{~kW}$ photovoltaic power plant, 8) $1 \mathrm{MW}$ photovoltaic power plant, 9) $100 \mathrm{MW}$ photovoltaic power plant, 10) natural gas-fired gas-steam CHP unit with 3-pressure heat recovery steam generator (HRSG) and interstage steam reheat, 11) natural gas-fired gas-steam CHP unit with 2-pressure HRSG, 12) natural gas-fired gas-steam CHP unit with 1-pressure HRSG, 13) medium-capacity hard coal-fired steam CHP unit,

14) medium-capacity biomass-fired steam CHP unit, 15) natural gas-fired gas CHP unit with gas engine,

16) natural gas-fired gas CHP unit with simple cycle gas turbine, 17) small-capacity biomass-fired ORC (Organic Rankine Cycle) CHP unit, 18) small-capacity biomass-fired steam CHP unit, 19) CHP unit integrated with biological conversion biomass energy and 20) $\mathrm{CHP}$ unit integrated with biomass gasification, with $\mathrm{CO}_{2}$ emission payment

$$
\text { (248 } \left.\mathrm{PLN} / \mathrm{MgCO}_{2}\right)
$$

Rys. 1. Jednostkowe, zdyskontowane na 2021 r., koszty wytwarzania energii elektrycznej w elektrowniach systemowych, elektrociepłowniach dużej i średniej mocy oraz elektrowniach i elektrociepłowniach małej mocy [zł/MWh] dla: 1) bloku parowego na parametry nadkrytyczne opalanego węglem brunatnym, 2) bloku parowego na parametry nadkrytyczne opalanego węglem kamiennym, 3) bloku gazowo-parowego opalanego gazem ziemnym,

4) bloku jądrowego z reaktorem PWR, 5) lądowej elektrowni wiatrowej, 6) morskiej elektrowni wiatrowej, 7) mikroelektrowni fotowoltaicznej o mocy ok. $5 \mathrm{~kW}, 8$ ) elektrowni fotowoltaicznej o mocy ok. $1 \mathrm{MW}, 9)$ elektrowni

fotowoltaicznej o mocy ok. $100 \mathrm{MW}, 10$ ) ciepłowniczego bloku gazowo-parowego z 3-ciśnieniowym kotłem odzysknicowym i międzystopniowym przegrzewaniem pary opalanego gazem ziemnym, 11) ciepłowniczego bloku gazowo-parowego z 2-ciśnieniowym kotłem odzysknicowym opalanego gazem ziemnym, 12) ciepłowniczego bloku gazowo-parowego z 1-ciśnieniowym kotłem odzysknicowym opalanego gazem ziemnym, 13) ciepłowniczego bloku parowego średniej mocy opalanego węglem kamiennym, 14) ciepłowniczego bloku parowego średniej mocy opalanego biomasą, 15) ciepłowniczego bloku gazowego z silnikiem gazowym opalanego gazem ziemnym, 16) ciepłowniczego bloku gazowego z turbiną gazową pracującą w obiegu prostym opalanego gazem ziemnym), 17) ciepłowniczego bloku ORC opalanego biomasą, 18) ciepłowniczego bloku parowego małej mocy opalanego biomasą, 19) ciepłowniczego bloku zintegrowanego z biologiczną konwersją biomasy i 20) ciepłowniczego bloku zintegrowanego ze zgazowaniem biomasy, z uwzględnieniem kosztów uprawnień do emisji $\mathrm{CO}_{2}\left(248 \mathrm{z} / / \mathrm{MgCO}_{2}\right)$ 


\section{Summary}

The main challenge related to the sustainable development of generation sources in NEPS in the upcoming 30 years lies in synchronizing the decommissioning of coal- and lignite-fired condensing steam units working as CDGUs in NEPS with the construction (launch) of new units that would take over this role, ensuring NEPS operational security. The analyses showed that nuclear units should function as new CDGUs as they are characterized by zero emission and operational continuity, important for NEPS security, as well as the lowest, out of CDGUs (system power plants) analyzed, unit costs of electricity generation discounted for 2021 and amounting to 256 PLN/MWh (Fig. 1).

There should be no CDGUs' capacity deficit in NEPS by 2030. Between 2021 and 2030, 14 coal- and lignite-fired units of $200 \mathrm{MW}$ are expected to be decommissioned, in the following power plants: Dolna Odra, Łaziska, Ostrołęka, Pątnów and Rybnik. Their total capacity amounts to circa $3.1 \mathrm{GW}$. This capacity loss will be compensated by the simultaneous launch of low-emission transitional sources, three gas-steam condensing units (two in the Dolna Odra power plant and one in the Ostrołęka power plant), of total capacity reaching circa $2.1 \mathrm{GW}$, as well as one gas-steam CHP unit whose capacity is circa $0.5 \mathrm{GW}$, in the Żeran CHP plant, fired with natural gas. The existing NEPS overcapacity will also be used.

Between 2030 and 2035 two nuclear units of total capacity amounting to circa 2.5 GW (MP 2020) and several gas-steam CHP units should be launched in NEPS. In addition, offshore wind power plants whose capacity is to equal circa $6 \mathrm{GW}$ will have been in use: Their duration of installed capacity utilization will be reaching a significantly higher value (i.e. circa 3,400 h/year) than the one of existing wind power plants (i.e. circa 1,900 h/year) and photovoltaic power plants (circa $950 \mathrm{~h} /$ year) which should translate into a lower demand for CDGUs' capacity in NEPS. Between 2035 and 2040 two other nuclear power units, of combined capacity amounting to circa $2.5 \mathrm{GW}$, should be launched in NEPS. The capacity of off-shore wind power plants is expected to increase to circa $12 \mathrm{GW}$.

Irrespective of CDGUs, cogeneration units constitute another group of NEPS generation sources which needs a significant fuel and technological transformation. Currently, the largest share of cogeneration units whose total capacity amounts to circa 7,058.8 MW (63.1\%), is represented by coal-fired steam CHP units of relatively low energy effectiveness and high $\mathrm{CO}_{2}$ emission. For this reason, this group, similarly to CDGUs, needs a technological and fuel transformation. Natural gas-fired, gas-steam CHP units with 3-pressure HRSG and interstage steam reheating constitute a good interim (until 2040) solution for large-capacity heating systems, as they are characterized by energy and economic effectiveness and low $\mathrm{CO}_{2}$ emission. For these units, unit costs of electricity generation, including $\mathrm{CO}_{2}$ emission allowances, discounted as for 2021, amount to circa PLN 284 /MWh. In turn, for medium-capacity heating systems, there is an alternative in the form of gas-steam CHP units with 2- and 1-pressure HRSGs. For these units, unit costs of electricity generation, including $\mathrm{CO}_{2}$ emission allowances, discounted as for 2021, amount to circa PLN 300-328/MWh. Technologies usable in small-capacity CHP units 
(dispersed cogeneration sources) unit costs of electricity generation, discounted as for $2021 \mathrm{can}$ be assigned to small-capacity cogeneration sources fired with natural gas, with gas engines and small-capacity simple-cycle gas turbines of nominal fuel capacity below $20 \mathrm{MW}$, which are bound to buy $\mathrm{CO}_{2}$ emission allowances. For these units, unit costs of electricity generation, discounted as for 2021 amount to circa PLN 328-335/MWh (Fig. 1).

The use of biomass in the process of Polish electric power industry transformation to reach climate neutrality constitutes an important issue. Currently, the most effective biomass use, economy-wise, takes place in medium-capacity steam CHP units whose unit costs of electricity generation, discounted for 2021, amount to circa PLN 306/MWh (Fig. 1). The use of biomass in dispersed sources constitutes a more complex issue. Only technologies based on biomass burning in small-capacity steam CHP units and ORC units, and on biological conversion of biomass chemical energy, have reached commercial maturity. At the same time, biomass-based technologies are characterized by low energy effectiveness and by the same token, by high electricity production costs. In order to achieve relatively good economic effectiveness, these technologies need to function in full cogeneration, at a long time of installed electrical and heat capacity utilization.

The analyses indicate that Poland can reach climate neutrality around 2055. By that time, about $55 \%$ of electricity should have been produced by zero-emission offshore and onshore wind power plants and photovoltaic power plants, about $25 \%$ of electricity - by zero-emission nuclear power plants, to secure NEPS operation, and about $20 \%$ of electricity - by CHP plants fired with biomass or biogas and natural gas, to ensure system heat production. The calculations showed that the unit costs of electricity production, discounted for 2021, in zero-emission wind, photovoltaic and nuclear power plants do not exceed PLN 360/MWh (Fig. 1).

This paper assumed that the use of coal in the Polish electric power industry both in condensing and in cogeneration steam units, will be gradually decreasing: from $70 \%$ in 2020 to circa $57 \%$ in 2030 and further to $26 \%$ in 2040 to reach circa $6 \%$ in 2050 , so that the mining industry could be involved in the coal-minimizing process according to the rule of fair transformation.

\section{References}

ARE 2021. Statistical Information on Electricity (Informacja statystyczna o energii elektrycznej). Agencja Rynku Energii SA, Nr 6, Warszawa (in Polish).

BP 2021. BP Statistical Review of World Energy, Edition 2021. [Online] https://www.bp.com/en/global/ corporate/energy-economics/statistical-review-of-world-energy.html [Accssed: 2021-09-17].

Directive 2005/89. Directive 2005/89/UE of the European Parliament and Council of 18 January 2006 on concerning measures to safeguarded security of electricity supply and infrastructure investment. Official Journal of the European Union, 2006, L 33/1 - L33/22.

Directive 2012/27. Directive 2012/27/UE of the European Parliament and Council of 25 October 2012 on energy efficiency. Official Journal of the European Union, 2012, L 315/1 - L315/56.

KPEiK 2019. National Energy and Climate Plan 2021-2030 (Krajowy plan na rzecz energii i klimatu na lata 2021-2030). Ministerstwo Aktywów Państwowych, 2019 (in Polish). 
MP 2020. Polish Nuclear Power Programme (Program polskiej energetyki jądrowej). Monitor Polski 2020, poz. 946 (in Polish).

PSE 2016. Forecast of Peak Capacity Demand Coverage in 2016-2035 (Prognoza pokrycia zapotrzebowania szczytowego na moc w latach 2016-2035). Polskie Sieci Elektroenergetyczne SA. [Online] https:// www.pse.pl/-/prognoza-pokrycia-zapotrzebowania-szczytowego-na-moc-w-latach-2016-2035 [Accessed: 2021-08-10] (in Polish).

PSE 2020. Development Plan of Present and Future Electricity Satisfaction Demand Coverage in 2021-2035 (Plan rozwoju $w$ zakresie zaspokojenia obecnego i przyszłego zapotrzebowania na energie elektryczna na lata 2021-2030). Polskie Sieci Elektroenergetyczne SA. [Online] https://www.pse.pl/ documents/20182/21595261/Dokument_glowny_PRSP_2021-2030_20200528.pdf [Accessed: 2021-08-10] (in Polish).

PEP2040 2021. Energy Policy of Poland until 2040 (Polityka energetyczna Polski do 2040 roku). MP 2021, poz. 128 (in Polish).

Statistics 2019. Statistics of Polish Heat Industry 2018 (Statystyka Cieplownictwa Polskiego 2018). Warszawa: Agencja Rynku Energii SA (in Polish).

Statistics 2020. Statistics of Polish Electric Power Industry 2019 (Statystyka Elektroenergetyki Polskiej 2019). Warszawa: Agencja Rynku Energii SA (in Polish).

URE 2020. Information about Investment Plans in New Generation Capacity in 2020-2034 (Informacja na temat planów inwestycyjnych w nowe moce wytwórcze w latach 2020-2034). Urząd Regulacji Energetyki. [Online] https://www.ure.gov.pl $>$ download $>$ Raport-Plany inwestycyjne w nowe moce wytwórcze latach 2020-2034 [Accessed: 2021-08-10] (in Polish).

ZAPOROWSKI, B. 2016. Sustainable development of the electricity generation sources (Zrównoważony rozwój źródel energii elektrycznej). Polityka Energetyczna - Energy Policy Journal 19(3), pp. 35-48 (in Polish).

ZAPOROWSKI, B. 2019. Energy and economic effectiveness of prospective generation technologies for Polish electric power industry (Efektywność energetyczna i ekonomiczna perspektywicznych dla polskiej elektroenergetyki technologii wytwórczych). Zeszyty Naukowe Wydziału Elektrotechniki i Automatyki Politechniki Gdańskiej 63, część 2, pp. 87-90 (in Polish).

\section{Zrównoważony rozwój źródeł wytwórczych w Krajowym Systemie Elektroenergetycznym}

\section{Streszczenie}

W artykule przedstawiono analizę zrównoważonego rozwoju źródeł wytwórczych w Krajowym Systemie Elektroenergetycznym (KSE). Sformułowano kryteria zrównoważonego rozwoju systemu elektroenergetycznego. Przedstawiono aktualny stan źródeł wytwórczych w KSE, pracujących w elektrowniach i elektrociepłowniach. Opracowano prognozę bilansu mocy w KSE, wyznaczając: prognozowaną wartość 
zużycia elektrycznej brutto, obciążenia KSE w szczycie zimowym i szczycie letnim oraz wymaganej mocy JWCD i mocy źródeł rozproszonych, narastająco na lata 2025, 2030, 2035 i 2040, dla bezpieczeństwa pracy KSE. Zdefiniowano 20 przyszłościowych technologii wytwarzania energii elektrycznej i skojarzonego wytwarzania energii elektrycznej i ciepła, podzielonych na trzy następujące grupy: elektrownie systemowe, elektrociepłownie dużej i średniej mocy oraz elektrownie i elektrociepłownie małej mocy (źródła rozproszone). Dla wybranych do analizy technologii wytwórczych wyznaczono jednostkowe, zdyskontowane na 2021 rok, koszty wytwarzania energii elektrycznej, z uwzględnieniem kosztów uprawnień do emisji $\mathrm{CO}_{2}$. W kosztach tych uwzględniono: koszty kapitałowe, koszty paliwa, koszty remontów, koszty obsługi i koszty środowiskowe. Opracowano propozycję programu zrównoważonego rozwoju źródeł wytwórczych w KSE, wyznaczając pożądaną strukturę mocy elektrowni i elektrociepłowni oraz produkcji energii elektrycznej w latach 2030 i 2040.

SŁOWA KLUCzowe: zrównoważony rozwój, Krajowy System Elektroenergetyczny (KSE), elektrownia, elektrociepłownia, koszty wytwarzania energii elektrycznej 